\title{
Kıl keçi ve Saanen x Kıl (F1, G1 ve G2) melez oğlakların 6. ay vücut ölçüleri ve bu ölçülere etki eden faktörlerin belirlenmesi
}

\author{
Hilal TOZLU ÇELİK${ }^{1}$, Mustafa OLFAZ ${ }^{2}$
}

10rdu Üniversitesi Ulubey Meslek Yüksekokulu, 52850 Ulubey/ORDU

${ }^{2}$ Ondokuz Mayıs Üniversitesi Ziraat Fakültesi Zootekni Bölümü, 55139, SAMSUN.

Alınıș tarihi: 03 Temmuz 2017, Kabul tarihi: 03 Kasım 2017

Sorumlu yazar: Hilal TOZLU ÇELİK, e-posta: hilalcelik@odu.edu.tr

\section{Öz}

Bu çalışma, Kıl keçi ve Saanen x Kıl (F1, G1 ve G2) melezi oğlaklarda 6 . ay vücut ölçüleri üzerine genotip, cinsiyet ve doğum tipi gibi faktörlerin etkilerinin araştırılması amacıyla yapılmıştır. Çalışma Amasya'nın Sarılar köyünde özel bir işletmede yürütülmüştür. 6. ay vücut ölçülerinden cidago yüksekliği, vücut uzunluğu, sağrı yüksekliği, göğüs genişliği, göğüs derinliği, göğüs çevresi ve ön incik çevresi özellikleri belirlenmiştir. Çalışma sonucunda Kıl keçi ve Saanen x Kıl F1 oğlakların 6. ay vücut ölçüleri, incelenen özellikler açısından benzer bulunmuştur. Bölgede yetiştirilen melezlerde Saanen genotip seviyesinin artmasıyla 6 . aydaki vücut ölçümlerinin azaldığı tespit edilmiştir.

Anahtar kelimeler: Keçi, melezleme, genotip, büyüme, cinsiyet, doğum tipi

6th month body measurements of Hair goat and Saanen x Hair (F1, B1 and B2) crossbred kids and determination of the factors affecting these measurements

\section{Abstract}

This study was conducted to investigate the effects of factors such as genotype, gender, and type of birth on 6 month body measurements in Hair goat and Saanen x Hair (F1, B1 and B2) crossbreed. The study was carried out in a private establishment in Sariyar village of Amasya. From the 6th month body measurements, withers height, rump height, body length, chest width, chest depth, chest circumference and cannon bone circumference were determined.
As a result, $6^{\text {th }}$ month body measurements of Hair goat and Saanen x Hair F1 kids were found to be similar in terms of the characteristics examined. It has been determined that as the Saanen genotype level increases in the crossbreds grown in the region, the body measurements of the $6^{\text {th }}$ month decrease.

Key words: Goat, crossbreeding, genotype, growth, sex, birth type

\section{Giriş}

Keçi, geçmişten günümüze kadar süt, et, yapağı (tiftik, elyaf, kaşmir) ve deri üretimi ile insanlar için önemli bir kaynak durumundadır. Keçinin gelecek yıllarda da insanlar için sağlayacağı faydalar artarak devam edecektir (Samuel Fajemilehin ve Salako, 2008). Keçi yetiştiriciliği, insanların beslenmesinde önemli yeri olan hayvansal protein ihtiyacını karşılamanın yanında yüksek rakımlı kıraç alanlarda istihdam sağlayarak gelir kaynağı oluşturmaktadır. $\mathrm{Bu}$ kapsamda keçilerden maksimum fayda elde etmek için bilinçli bir yetiştiricilik yapılması gerekir.

Büyüme ve gelişme özellikleri erken seleksiyon kriteri olarak kullanılabilir. Yetiştiriciliğin ana hedefi birim hayvandan en kısa sürede ve maksimum fayda elde etmektir. Büyüme, hücre ve dokulardaki kütle ve hacim artışı olup genotip ve çevre koşullarına göre bazı farklılıklar gösterir. Büyüme, belirli bir yaşa kadar devam eder (Chacon ve ark., 2011). Hayvanlarda genotip, cinsiyet, doğum tipi, besleme çevresi, yaş, doğum yılı ve ana yaşı gibi bazı makro çevre faktörlerinin vücut ölçülerini etkilediği belirlenmiştir (Mohammed ve Amin 1996; Riva ve ark., 2004; Uğur ve ark., 2004). Periyodik olarak 
alınan vücut ölçüleri ve canlı ağırlıklar, hayvanın ırk özellikleri ve bakım-besleme şartlarını yansıtan ölçütlerdir. $\mathrm{Bu}$ nedenle farklı bakım-besleme koşullarında büyütülen hayvanların büyüme performanslarında farklılıklar vardır (Çam ve ark., 2010). Vücut ölçüleri, aynı ırk içinde seleksiyon yapabilme imkânı sağlayan önemli veri kaynaklarıdır (Bolacalı ve Küçük, 2012; Riva ve ark., 2004). Keçilerde cüsse, katım ya da aşım dönemindeki ağırlık için kullanılır. İyi bir büyüme ve gelişme ilk damızlıkta kullanma yaşının erkene alınmasına olanak sağlayabilir (Keskin, 2012).

Çiftlik hayvanlarında büyüme ve gelişme özellikleri dikkate alınarak erken yaşta seleksiyon ve ekonomik yetiştiricilik yapılabilmesi bakımından önemlidir. $\mathrm{Bu}$ çalışma ekstansif şartlarda yetiştirilen Kıl keçi ve Saanen x Kıl melez oğlakların 6. ay vücut ölçülerini belirlemek ve bu ölçülere etki eden faktörleri tespit etmek amacıyla yapılmıştır.

\section{Materyal ve Yöntem}

\section{Hayvan materyali}

Araştırma, Amasya'nın Merkeze bağlı Sarılar köyünde (40³9'35.89"K, 3552'36.25"D) özel bir işletmede yürütülmüştür. İşletmenin deniz seviyesinden yüksekliği ortalama 1150 metredir (Anonim, 2012). İşletmenin bulunduğu arazi tamamen kayalık bir yapıya sahiptir. Araştırmanın hayvan materyalini işletmede 2011 yılında doğan 14 baș Saanen x Kıl F1, 57 baş Saanen x Kıl G1, 9 baş Saanen x Kıl G2 ve 39 baş saf Kıl keçi olmak üzere toplam 119 baş oğlak oluşturmuştur. Doğan yavrulardan Kıl keçi oğlakların genellikle siyah renkli, Saanen x Kıl keçi melezlerinin genelinin beyaz renkli olduğu tespit edilmiştir. Oğlaklara doğumu takip eden 24 saat içinde kulak numaraları takılmış, genotip, cinsiyet ve doğum tipi gibi bilgiler bireysel olarak kaydedilmiştir. Sürüde doğan oğlakların \%77.31'i tekiz, \%22.69'u ikiz olmuştur.

\section{Hayvanların bakım ve beslenmesi}

Oğlaklar analarını 75 günlük yaşa ulaşıncaya kadar analarını emmişler ve daha sonra sütten kesilmişlerdir. Oğlaklar yetiştiricinin uyguladığı besleme sistemine göre büyütülmüşlerdir. Oğlaklar analarını sabah ve akşam emmişler, ayrıca oyalanmaları ve rumen gelişimi için doğumdan 2 hafta sonra kuru pelit yaprağı verilmiştir.

\section{Hayvanların vücut ölçülerinin belirlenmesi}

Oğlaklar 6 aylık yaşa ulaştıklarında büyüme ve gelişme özelliklerini belirlemek için cidago yüksekliği, vücut uzunluğu, sağrı yüksekliği, göğüs genişliği, göğüs derinliği, göğüs çevresi ve ön incik çevresi ölçümleri alınmıştır. Vücut ölçülerinden cidago yüksekliği (yer ile cidago arası), vücut uzunluğu (omuz ucundan oturak yumrusuna kadar olan uzaklık), sağrı yüksekliği (tuber coxae'ları birleştiren hattın yere olan düşey uzaklığı), göğüs genişliği (kürekler arkasında bulunan çukurluklar arası uzaklıktır), göğüs derinliği (cidago ile göğüs kemiği arasındaki düşey uzaklık) ölçü bastonu ile göğüs çevresi (cidago ve sternumdan geçen ve göğsü tamamen çevreleyen ölçü) ve ön incik çevresi (meta carpus kemiğinin en ince yerinin çevresi) ise ölçü şeridi ile tespit edilmiştir (Çam ve ark., 2010).

\section{İstatistiksel analizler}

Araştırmada Kıl keçi ve Saanen x Kıl F1, G1 ve G2 melezlerinin büyüme özelliklerinin belirlenmesi amacıyla 6 aylık vücut ölçüleri alınarak değerlendirilmiştir. Cidago yüksekliği, vücut uzunluğu, sağrı yüksekliği, kürek arkası göğüs genişliği, göğüs derinliği, göğüs çevresi ve ön incik çevresi gibi vücut ölçüleri üzerine genotip, doğum tipi, cinsiyet gibi faktörlerin etkisini saptamak üzere, varyansların homojenliği Levene varyans homojenlik testi ile değerlendirilmiştir. Analiz sonuçlarına göre varyanslar homojen olduğu tespit edildikten sonra varyans analizi uygulanmıştır. Faktörlerin önemli bulunması durumunda ortalamaları karşılaştırmak için Duncan çoklu karşılaştırma testi kullanılmıştır (Düzgüneş ve ark., 2003). Verilerin değerlendirilmesinde SPSS istatistik programı kullanılmıştır. Kullanılan analiz yönteminin matematik modeli aşağıda verilmiştir.

Yijkl $=\mu+a i+b j+c k+e i j k l$

$\mu=$ Populasyon ortalaması

ai= i. genotipin etkisi

$\mathrm{bj}=\mathrm{j}$. cinsiyetin etkisi

ck=k. doğum tipinin etkisi

eijkl=normal, bağımsız ve şansa bağlı hata

\section{Bulgular ve Tartışma}

Hayvanlarda vücut ölçüleri üzerine genotip etkisi ile birlikte yetiștirme sisteminin de etkisi vardır (Bolacalı ve Küçük, 2012). Merada yetiştirilen yerli Irklar vitamin ve mineral eksikliklerinden muzdarip oldukları gibi yem miktar ve kalitesindeki sınırlamalar vücut ölçülerini etkileyebilir (Kadim ve ark., 2006). Vücudun şekillenmesinde çevresel faktörler etkili olmasına rağmen temelde kalıtsal 
özellikler sonucunda ortaya çlkar (Chacon ve ark., 2011). Bir batında doğan yavru sayısının artması ile doğan yavruların vücut ölçülerinde farklılıkların olması beklenen bir durumdur (Tüfekci ve Olfaz, 2016). Cinsiyet, farklı yaşlardaki keçilerde vücut ölçüleri üzerine önemli etkiye sahiptir (Samuel Fajemilehin ve Salako, 2008). Melezleme çalışmalarında melez ve saf genotipler arasındaki farklılıklarda genotipik farklılıkların yanında bakım ve besleme gibi çevre faktörlerinin de payı vardır (Şimşek ve ark., 2007). Oğlakların 6. ay vücut ölçüleri ve bunlara etki eden faktörler ile ilgili bulgular Çizelge 1'de verilmiştir.

Çizelge 1. Oğlakların 6. ay vücut ölçülerine ait en küçük kareler ortalamaları ve standart hataları (Cidago yüksekliği, vücut uzunluğu, sağrı yüksekliği, göğüs genişliği, göğüs derinliği, göğüs çevresi, ön incik çevresi) $(\mathrm{X} \pm \mathrm{Sx})$

\begin{tabular}{|c|c|c|c|c|c|c|c|c|}
\hline Özellikler & $\mathrm{n}$ & $\begin{array}{l}\text { Cidago } \\
\text { Yüksekliği } \\
(\mathrm{cm})\end{array}$ & $\begin{array}{l}\text { Vücut } \\
\text { Uzunluğu } \\
\text { (cm) }\end{array}$ & $\begin{array}{c}\text { Sağrı } \\
\text { Yüksekliği } \\
(\mathrm{cm})\end{array}$ & $\begin{array}{l}\text { Göğüs Genişliği } \\
(\mathrm{cm})\end{array}$ & $\begin{array}{l}\text { Göğüs Derinliği } \\
(\mathrm{cm})\end{array}$ & $\begin{array}{c}\text { Göğüs Çevresi } \\
(\mathrm{cm})\end{array}$ & $\begin{array}{l}\text { Ön İncik } \\
\text { Çevresi } \\
(\mathrm{cm})\end{array}$ \\
\hline \multicolumn{9}{|l|}{ Genotip } \\
\hline $\begin{array}{c}\% 50 \\
\text { Saanen }\end{array}$ & 14 & $61.29 \pm 0.93^{\mathbf{b}}$ & $57.07 \pm 0.89$ & $61.50 \pm 0.82^{b}$ & $14.93 \pm 0.35$ b & $25.00 \pm 0.35^{b}$ & $73.07 \pm 0.99 b$ & $8.89 \pm 0.14^{b}$ \\
\hline $\begin{array}{c}\% 75 \\
\text { Saanen }\end{array}$ & 57 & $59.40 \pm 0.55^{\mathbf{b}}$ & $55.74 \pm 0.64$ & $60.53 \pm 0.50^{\mathbf{b}}$ & $14.18 \pm 0.25^{a b}$ & $23.86 \pm 0.27^{\mathbf{a b}}$ & $70.72 \pm 0.78^{\mathrm{ab}}$ & $8.62 \pm 0.10^{\mathbf{b}}$ \\
\hline $\begin{array}{l}\% 87.5 \\
\text { Saanen }\end{array}$ & 9 & $56.33 \pm 0.99 a$ & $53.00 \pm 1.25$ & $57.33 \pm 1.25^{\mathrm{a}}$ & $13.33 \pm 0.44^{\mathrm{a}}$ & $22.78 \pm 0.57 \mathrm{a}$ & $67.00 \pm 1.46^{\mathrm{a}}$ & $8.22 \pm 0.21^{\mathrm{a}}$ \\
\hline Kll & 39 & $60.08 \pm 0.55^{b}$ & $56.56 \pm 0.80$ & $61.33 \pm 0.54^{b}$ & $14.28 \pm 0.20$ ab & $23.77 \pm 0.33^{\mathrm{ab}}$ & $70.85 \pm 0.68^{a b}$ & $8.72 \pm 0.10^{b}$ \\
\hline Genel & 119 & $59.61 \pm 0.36$ & $55.96 \pm 0.43$ & $60.66 \pm 0.33$ & $14.24 \pm 0.15$ & $23.88 \pm 0.18$ & $70.76 \pm 0.47$ & $8.66 \pm 0.06$ \\
\hline $\begin{array}{l}\text { Önem } \\
\text { düzeyi }\end{array}$ & & $* *$ & & $*$ & * & * & $* *$ & $* *$ \\
\hline \multicolumn{9}{|l|}{ Cinsiyet } \\
\hline Erkek & 52 & $60.02 \pm 0.62$ & $56.42 \pm 0.73$ & $60.90 \pm 0.59$ & $14.38 \pm 0.24$ & $24.35 \pm 0.29$ & $71.44 \pm 0.75$ & $8.86 \pm 0.11$ \\
\hline Dişi & 67 & $59.30 \pm 0.36$ & $55.60 \pm 0.52$ & $60.48 \pm 0.38$ & $14.12 \pm 0.19$ & $23.52 \pm 0.22$ & $70.22 \pm 0.60$ & $8.50 \pm 0.70$ \\
\hline $\begin{array}{l}\text { Önem } \\
\text { düzeyi }\end{array}$ & & & & & & $*$ & & \\
\hline \multicolumn{9}{|l|}{$\begin{array}{l}\text { Doğum } \\
\text { tipi }\end{array}$} \\
\hline Tekiz & 92 & $60.14 \pm 0.40$ & $56.77 \pm 0.45$ & $61.03 \pm 0.39$ & $14.46 \pm 0.16$ & $24.14 \pm 0.20$ & $71.50 \pm 0.52$ & $8.78 \pm 0.07$ \\
\hline İkiz & 27 & $57.81 \pm 0.72$ & $53.19 \pm 0.97$ & $59.41 \pm 0.63$ & $13.48 \pm 0.33$ & $23.00 \pm 0.36$ & $68.22 \pm 0.97$ & $8.24 \pm 0.13$ \\
\hline $\begin{array}{l}\text { Önem } \\
\text { düzeyi }\end{array}$ & & $* *$ & $*$ & * & $* *$ & * & $* *$ & $* *$ \\
\hline
\end{tabular}

Not: ${ }^{*}: \mathrm{P}<0.05,{ }^{* *}: \mathrm{P}<0.01, \mathrm{a}, \mathrm{b}$, ab: Aynı sütunda farklı harfleri taşıyan değerler arasındaki fark önemlidir. 


\section{Cidago yüksekliği}

Çizelge 1'de genotipin ve doğum tipinin cidago yüksekliği üzerine etkisi önemli $(\mathrm{P}<0.01)$ bulunmuş, Saanen x Kıl G2 melezlerin cidago yüksekliğinin diğer melezler ve Kıl keçiden daha düşük değerde olduğu tespit edilmiştir. Tek doğanlar ikizlerden daha yüksek cidagoya sahiptir. Araștırma bulgularına göre Saanen x Kıl F1, Saanen x Kıl G1 ve Kıl keçi oğlaklarının cidago yüksekliklerinin benzer olduğu tespit edilmiştir. Çalışma sonucunda cidago yüksekliği Saanen x Kıl F1, Saanen x Kıl G1, Saanen x Kıl G2 genotiplerinde ve Kıl keçilerde sırasıyla; 61.29 $\mathrm{cm}, 59.40 \mathrm{~cm}, 56.33 \mathrm{~cm}$ ve $60.08 \mathrm{~cm}$ olarak belirlenmiștir.

Saanen oğlaklarda doğum tipinin 6. ay cidago yüksekliğini etkilediği bildirilmektedir (Bolacalı ve Küçük, 2012). Çalışmada elde edilen doğum tipinin cidago yüksekliğine etkisi Bolacalı ve Küçük (2012)'ün bildirdiği ile uyumludur. Bolacalı ve Küçük (2012) tarafından Saanen oğlaklarında 180 günlük cidago yüksekliği $56.7 \mathrm{~cm}$ bulunmuştur. Cengiz ve ark. (1995) Akkeçi (Saanen x Kilis G1) oğlaklarının 6. ay cidago yüksekliğini tekiz erkeklerde $56.77 \mathrm{~cm}$, tekiz dişilerde $52.71 \mathrm{~cm}$, ikiz erkeklerde $53.82 \mathrm{~cm}$, ikiz dişilerde $52.14 \mathrm{~cm}$ tespit etmişlerdir. Şimşek ve Bayraktar (2006) Kıl Keçisi ve Saanen x Kıl Keçisi F1 genotipinde 6. ay cidago yüksekliğini sırasıyla $52.66 \mathrm{~cm}$ ve $53.05 \mathrm{~cm}$ olarak belirlemişlerdir. Çalışmada elde edilen bulgular, Erduran ve Yaman (2012)'ın (Kıl keçi, Saanen x Kıl (F1) ve Alpin x Kıl (F1) melezi oğlakların 6. ay cidago yüksekliği sırasıyla $64.65 \mathrm{~cm}, 65.35 \mathrm{~cm}$ ve $65.46 \mathrm{~cm}$ ) bildirdiklerinden düşük, Yılmaz ve ark. (2013)'ın (Kıl keçi ve Saanen x Kıl F1 için 6. ay cidago yüksekliği sirasiyla $52.3 \mathrm{~cm}, 54.5 \mathrm{~cm}$ ), Cengiz ve ark. (1995), Şimşek ve Bayraktar (2006) ve Bolacalı ve Küçük (2012)'ün elde ettiği sonuçlardan daha yüksektir. Bu sonucun, yetiştiricinin hayvanlara sağladığı bakım ve besleme, yöresel flora farklılıkları ve teke etkisinden kaynaklanabileceği düşünülmektedir. Çam ve ark. (2010) tarafından Kıl keçilerin vücut ölçüleri kullanılarak vücut ağırlığı tahmini üzerine yapılan bir araştırmada Kıl keçilerin vücut uzunluğu, sağrı yüksekliği ve cidago yüksekliği ölçülerinin birbirine yakın değerlerde olduğu ve bu ölçülerin et tipi özelliklerinin (kare biçimli) belirtileri olduğu bildirilmektedir. Kıl keçilerin cidago ve sağrı yüksekliği arasında iyi bir denge olması, tepelere tırmanma ve aşağıya inme için bir avantajdır. Ayrıca bacak uzunluğunun, dikenli ve çalılık olan olumsuz çevre koşullarında keçilerin vücudunun yaralanmadan uzun süre yürümelerini sağlayan bir avantaj olduğu bildirilmektedir (Çam ve ark., 2010). Çalışma sonucunda Kıl keçilerin vücut uzunluğu, cidago yüksekliği ve sağrı yüksekliği değerlerinin birbirine yakın olduğu tespit edilmiş olup Çam ve ark. (2010)'ın bildirdikleri et tipi göstergeleri ile uyumludur. Kıl keçilerin bu vücut ölçülerine bakılarak yetiştiricilerin uygulayacağı besleme programı ile daha fazla et elde edilebilecektir. Keçilerde cidago yüksekliği ve canlı ağırlığı yüksek olan hayvanların seçilerek damızlığa ayrılması ile süt veriminde artış sağlanabileceği bildirilmektedir (Keskin, 2012).

\section{Vücut uzunluğu}

Çalışma sonucunda doğum tipinin vücut uzunluğu üzerine etkisi önemli $(\mathrm{P}<0.05)$ bulunmuş, tek doğanların ikizlerden daha yüksek vücut uzunluğuna sahip olduğu belirlenmiş (Çizelge 1) olup Bolacalı ve Küçük (2012)'ün Saanen keçileri için elde ettiği sonuç ile benzerdir.

Hayvanın iskelet yapısının büyüklügü süt verimine olumlu etkilemektedir (Güney ve Kaymakçı, 1997). Vücut uzunluğunun fazla olması et veriminin iyi olacağının bir göstergesidir. Süt verim yönlü hayvanların büyümesi yavaș ve vücutları uzun, bacakları ince ve uzun bir görünüme sahiptir (Bolacalı ve Küçük, 2012). Cengiz ve ark. (1995) Akkeçi oğlaklarının 6. ay vücut uzunluğunu tekiz erkeklerde $53.60 \mathrm{~cm}$, tekiz dişilerde $52.34 \mathrm{~cm}$, ikiz erkeklerde $52.89 \mathrm{~cm}$, ikiz dişilerde $50.93 \mathrm{~cm}$ olarak tespit etmiştir. Şimşek ve Bayraktar (2006) tarafından Kıl Keçisi ve Saanen x Kıl F1 genotipinde 6. ay vücut uzunluğunun sirasıyla; $50.80 \mathrm{~cm}$ ve 52.64 $\mathrm{cm}$ olduğu belirlenmiştir. Bu çalışma sonucunda Kıl keçileri $(56.56 \mathrm{~cm})$ ve Saanen x Kıl F1 genotipi $(57.07 \mathrm{~cm})$ için elde edilen bulguların; Erduran ve Yaman (2012)'ın (Kıl keçi, Saanen x Kıl (F1) ve Alpin $x$ Kıl (F1) melezi oğlaklarında sırasıyla $52.81 \mathrm{~cm}$, $53.13 \mathrm{~cm}$ ve $53.36 \mathrm{~cm}$ ), Yllmaz ve ark. (2013)'nın (Kıl keçi ve Saanen x Kıl F1 için sırasıyla $53.2 \mathrm{~cm}, 56.1$ $\mathrm{cm}$ ) ve Şimşek ve Bayraktar (2006)'ın elde ettiği 6 . ay vücut uzunluğu sonuçlarından daha yüksek değerlerde olduğu tespit edilmiştir. Araştırma da melezlerden Saanen x Kıl G1 genotipi ve Saanen x Kıl G2 genotipi için vücut uzunluğu sırasıyla; $55.74 \mathrm{~cm}$ ve $53.00 \mathrm{~cm}$ belirlenmiștir.

Melezlemede Saanen genotip seviyesi arttıkça vücut uzunluğu azalmıştır. Bolacalı ve Küçük (2012) tarafından Saanen oğlaklarında 180 günlük vücut uzunluğu $58.3 \mathrm{~cm}$ olarak tespit edilmiştir. Çalışmada 
elde edilen bulgular Cengiz ve ark. (1995)'nın Akkeçi oğlakları ve Bolacalı ve Küçük (2012)'ün Saanen oğlakları için bildirdikleri değerlerden farklıdır.

\section{Sağrı yüksekliği}

Çalışma sonucunda Kıl keçi, Saanen x Kıl F1, Saanen x Kıl G1 ve Saanen x Kıl G2 için sağrı yüksekliği sirasiyla $61.33 \mathrm{~cm}, 61.50 \mathrm{~cm}, 60.53 \mathrm{~cm}$ ve $57.33 \mathrm{~cm}$ olarak tespit edilmiştir. Çizelge 1 'de görüldüğğ gibi sağrı yüksekliği üzerine genotip ve doğum tipinin etkisi önemli $(\mathrm{P}<0.05)$ bulunmuş, Saanen x Kıl G2 melezlerinin diğerlerine göre daha düşük sağrı yüksekliğine ve ikizlerin tek doğanlardan daha az sağrı yüksekliğine sahip olduğu tespit edilmiştir.

Erduran ve Yaman (2012) tarafindan Kıl keçi, Saanen x Kıl (F1) ve Alpin x Kıl (F1) melezi oğlakların 6. ay sağrı yüksekliği sırasıyla $65.49 \mathrm{~cm}, 66.19 \mathrm{~cm}$ ve $66.25 \mathrm{~cm}$ olarak bulunmuștur. Çalıșma sonucunda elde edilen bulgular Erduran ve Yaman (2012)'ın bildirdiğinden düşük bulunmuștur. Bolacalı ve Küçük (2012) Saanen keçilerinin 180. gün sağr yüksekliğine doğum tipinin etkili olduğunu belirlemiş olup, bu sonuç ile çalışma bulguları benzerlik göstermektedir. Bolacalı ve Küçük (2012) Saanen keçilerinin 180. gün sağrı yüksekliğini 55.8 cm olarak tespit etmişlerdir.

Çalıșma sonucunda Kıl keçi ve Saanen x Kıl keçi melezlerinin sağrı yüksekliği için elde edilen bulgular Bolacalı ve Küçük (2012)'ün Saanen keçileri için bildirdiklerinden daha yüksektir. Bu farklılığın ana hattı olarak kullanılan Kıl keçilerinden kaynaklandığı düşünülmektedir. Kıl keçilerin sağrı yüksekliğinin melezlere göre daha yüksek, Kıl keçilere en yakın değerin Saanen $\mathrm{x}$ Kıl $\mathrm{F} 1$ genotipinde olduğu tespit edilmiştir. Malta keçilerinde cidago yüksekliği, sağrı yüksekliği ve canlı ağırlığın laktasyon süt verimi için dolaylı seleksiyon kriteri olarak kullanılabileceği bildirilmektedir (Keskin, 2012). Çalışma sonucunda genotipler için elde edilen cidago yüksekliği ve sağrı yüksekliği bulguları değerlendirilerek süt verim yönlü seleksiyon yapılabileceği düşünülmektedir.

\section{Göğüs genişliği}

Çizelge 1'de görüldüğü gibi göğüs genișliğini genotip $(\mathrm{P}<0.05)$ ve doğum tipi $(\mathrm{P}<0.01)$ önemli düzeyde etkilemiştir. Çalışma sonucunda Kıl keçi, Saanen x Kıl F1, Saanen x Kıl G1 ve Saanen x Kıl G2 genotipi için göğüs genişliği sırasıyla; $14.28 \mathrm{~cm}, 14.93 \mathrm{~cm}, 14.18$ cm ve $13.33 \mathrm{~cm}$ olarak bulunmuștur. Kıl keçi ve
Saanen x Kıl G1 melez oğlakların benzer göğüs genişliğine sahip oldukları tespit edilmiştir.

Bolacalı ve Küçük (2012) tarafından Saanen oğlaklarında 180 günlük gögüs genişliği $11.3 \mathrm{~cm}$ olarak bulunmuştur. Çalışma sonucunda Kıl keçi ve Saanen x Kıl (F1, G1 ve G2) melezler için elde edilen bulguların Bolacalı ve Küçük (2012)'ün bildirdiklerinden yüksek olduğu belirlenmiş, bu farklılığın Kıl keçilerin sahip olduğu göğüs genişliğinden kaynaklandığı düşünülmektedir. Erduran ve Yaman (2012)'ı (Kıl keçi, Saanen x Kıl (F1) ve Alpin x Kıl (F1) melezi oğlaklarda 6. ay göğüs genişliği sırasıyla $15.77 \mathrm{~cm}, 15.93 \mathrm{~cm}$ ve $15.89 \mathrm{~cm}$ ) bildirdikleri çalışma bulgularından yüksek bulunmuştur.

\section{Göğüs derinliği}

Göğüs derinliği üzerine genotip, cinsiyet ve doğum tipinin etkisinin önemli $\quad(\mathrm{P}<0.05) \quad$ olduğu belirlenmiştir (Çizelge 1). Bolacalı ve Küçük (2012) göğüs derinliğine doğum tipinin etkili olduğunu bildirmiș olup, çalıșma sonucu ile benzerdir.

Göğüs derinliği ve canlı ağırlık arasında yüksek korelasyon bulunduğu bildirilmektedir (Pesmen ve Yardimci, 2008). İyi bir göğüs gelişimi gösteren hayvanların daha sağlıklı olduğu ve daha yüksek rakımlı bölgelerde iyi bir solunum sistemine sahip olduğunun ve süt üretimi için daha uygun olduğunun göstergesi olduğu bildirilmektedir (Chacon ve ark., 2011). Çalışma sonucunda Kıl keçi, Saanen x Kıl F1, G1 ve G2 genotipleri için gögüs derinliği sırasıyla; $23.77 \mathrm{~cm}, 25.00 \mathrm{~cm}, 23.86 \mathrm{~cm}$ ve $22.78 \mathrm{~cm}$ olarak belirlenmiştir. Araştırma sonucunda Saanen x Kıl F1 melezlerin Saanen x Kil G1 ve Saanen x Kıl G2 melezlerden daha iyi bir göğüs derinliğine sahip olduğu, en düșük değerin ise Saanen $\mathrm{x}$ Kıl G2 melezlerde olduğu tespit edilmiştir. Saanen x Kıl F1 melezlerde göğus derinliğinin fazla bulunması beklenen bir durumdur.

Melezlemelerde F1 generasyonu genellikle yüksek değerlere sahip olur. Saanen x Kil F1 melez genotipin yüksek gelişim özellikleri sebebiyle kasaplık olarak yetiştirilmesi daha uygun olabilir. İşletmenin bulunduğu yerin rakımı yüksek olması sebebiyle solunum sistemi gelișmiș olan Saanen x Kıl G1 melezlerden damızlık olarak satışı yapılamayacak erkeklerinin et verimli yönlü olarak değerlendirilmesi, dișilerin ise süt verim yönlü yetiștirilmesinin uygun olacağı düşünülmektedir. Kıl keçilerin göğüs derinliğinin yüksek olması iyi bakım 
ve besleme ile daha fazla et elde edilmesini sağlayabilir.

Cengiz ve ark. (1995) tarafından Akkeçi oğlaklarının 6. ay göğüs derinliği tekiz erkeklerde $22.77 \mathrm{~cm}$, tekiz dișilerde $21.47 \mathrm{~cm}$, ikiz erkeklerde $21.42 \mathrm{~cm}$, ikiz dișilerde $20.43 \mathrm{~cm}$ bulunmuş ve 6 . ayda tekiz erkeklerin ikiz dişilere göre üstünlükleri önemli bulunmuştur. Bolacalı ve Küçük (2012) tarafından Saanen oğlaklarında 180 günlük göğüs derinliği 25.1 cm bulunmuştur. Çalışma sonucunda elde edilen bulgular Cengiz ve ark. (1995)'nın bildirdiklerinden yüksek ve Yılmaz ve ark. (2013)'nın (Kıl keçi ve Saanen x Kıl F1 için sırasıyla $25.7 \mathrm{~cm}, 25.7 \mathrm{~cm}$ ), Erduran ve Yaman (2012)'ın (Kıl keçi, Saanen x Kıl (F1) ve Alpin x Kıl (F1) melezi oğlaklarda 6. ay göğüs derinliği sırasıyla $25.73 \mathrm{~cm}, 25.87 \mathrm{~cm}$ ve $25.87 \mathrm{~cm}$ ) ve Bolacalı ve Küçük (2012)'ün bildirdiklerinden ise daha düşük olduğu tespit edilmiştir.

\section{Göğüs çevresi}

Çizelge 1 incelendiğinde Kıl keçi, Saanen x Kıl F1, Saanen x Kıl G1 ve Saanen x Kıl G2 genotipleri için 6 . ay göğüs çevresi ölçüleri sırasıyla; $70.85 \mathrm{~cm}, 73.07$ $\mathrm{cm}, 70.72 \mathrm{~cm}$ ve $67.00 \mathrm{~cm}$ olarak belirlenmiștir. Gögüs çevresi üzerine genotip ve doğum tipinin önemli $(\mathrm{P}<0.01)$ etkisi olduğu tespit edilmiştir. Çizelge 1 incelendiğinde Saanen x Kll G1 melezleri ile Kıl keçi oğlaklarının benzer değerlerde göğüs çevresine sahip olduğu görülmektedir. Göğüs bölgesinin iyi gelişmesinin genotip, besleme ve bakım şartlarının iyi olmasından kaynaklandığı ifade edilebilir.

Göğüs kemiğinin iyi gelişmiş olması kemik üzerinde et ve yağ birikiminin iyi olacağının göstergesi olarak bildirilmektedir (Chacon ve ark., 2011). Kıl keçilerinde gögüs çevresi ölçüsüne bakılarak yaş ve cinsiyet dikkate alınmadan vücut ağırlık tahmini yapılabilir. Göğüs çevresi, göğüs derinliği, göğüs genişliği ve vücut uzunluğu ölçülerinin birlikte değerlendirilmesi ile vücut ağırlığının doğru tahmin edilmesi için yeterli olduğu bildirilmektedir (Pesmen ve Yardımcı, 2008; Çam ve ark., 2010).

Canlı ağırlık ile göğüs çevresi ve göğüs derinliği arasında yüksek ilişki bulunmaktadır. Saanen keçileri üzerinde yapılan bir araştırmada canlı ağırlık ve göğüs çevresi arasında 0.843 korelasyon bulunduğu bildirilmektedir (Pesmen ve Yardımcl, 2008). Şimşek ve Bayraktar (2006) Kıl Keçisi ve Saanen x Kıl Keçisi F1 genotipinde 6. ay göğüs çevresini sırasıyla; $62.47 \mathrm{~cm}$ ve $62.00 \mathrm{~cm}$ olarak saptamış ve doğum tipinin göğüs çevresi üzerinde önemli etkisi olduğunu belirlemiştir. Cengiz ve ark. (1995) tarafından Akkeçi oğlaklarında 6. ay göğüs çevresi tekiz erkeklerde $59.10 \mathrm{~cm}$, tekiz dişilerde $56.27 \mathrm{~cm}$, ikiz erkeklerde $55.69 \mathrm{~cm}$, ikiz dişilerde $53.93 \mathrm{~cm}$ bulunmuştur. Araştırma sonucunda elde edilen bulgular ile Şimşek ve Bayraktar (2006)'ın doğum tipinin göğüs çevresine etkisinin önemli bulgusu ile benzer durumdadır. Bolacalı ve Küçük (2012) tarafından Saanen oğlaklarında 180 günlük göğüs çevresi $60.1 \mathrm{~cm}$ bulunduğu ve doğum tipinin göğüs çevresini etkilediği bildirilmektedir. Çalışma sonucunda elde edilen bulgular Erduran ve Yaman (2012)'ın (Kıl keçi, Saanen x Kıl (F1) ve Alpin x Kıl (F1) melezi oğlaklarda 6. ay gögüs çevresi sırasıyla $70.22 \mathrm{~cm}, 70.82 \mathrm{~cm}$ ve $71.00 \mathrm{~cm}$ ) bildirdikleri ile benzer, Yılmaz ve ark. (2013)'ın (Kıl keçi ve Saanen x Kıl F1 için sırasıyla $52.3 \mathrm{~cm}, 54.5 \mathrm{~cm}$ ), Cengiz ve ark. (1995), Şimşek ve Bayraktar (2006) ve Bolacalı ve Küçük (2012)'ün bildirdiklerinden yüksek bulunmuştur.

\section{Ön incik çevresi}

Ön incik çevresine genotip ve doğum tipinin etkisi önemli $(\mathrm{P}<0.01)$ bulunmuştur (Çizelge 1$)$. Ön incik çevresine ait ölçülen değerin yüksek olması iyi bir yürüyüş ve daha iyi tırmanma sağlaması açısından önemlidir. Bu açıdan melezler içerisinde Saanen x Kıl G2 melezleri en düşük ön incik çevresine sahiptir. Çalışma sonucunda 6. ay ön incik çevresi Kıl keçi, Saanen x Kıl F1, Saanen x Kıl G1 ve Saanen x Kıl G2 melez oğlaklarda sirasıyla $8.72 \mathrm{~cm}, 8.89 \mathrm{~cm}, 8.62 \mathrm{~cm}$ ve $8.22 \mathrm{~cm}$ olarak tespit edilmiştir. Bolacalı ve Küçük (2012) tarafından Saanen oğlaklarında 180 günlük ön incik çevresi $7.1 \mathrm{~cm}$ bulunmuştur.

Çalışma sonucunda elde edilen bulgularda Saanen melezlerinin ön incik çevre ölçüsünün Bolacalı ve Küçük (2012)'ün bildirdiklerinden daha yüksek olduğu, bu durumun Kıl keçi etkisinden kaynaklandığı düşünülmektedir. Erduran ve Yaman (2012) (Kıl keçi, Saanen x Kıl (F1) ve Alpin x Kıl (F1) melezi oğlaklarda 6. ay ön incik çevresi sırasıyla $10.86 \mathrm{~cm}, 10.82 \mathrm{~cm}$ ve $10.89 \mathrm{~cm}$ ) tarafından yapılan çalışmada bildirilen sonuçlar araştırma sonucunda elde edilen bulgulardan daha yüksek bulunmuştur.

Çalışma sonucunda elde edilen bulgular ile benzer çalışmalar arasındaki farklılıkların genotip ve bakımbesleme koşullarının farklılığı, sürü içindeki genotipik varyasyon, iklimsel farklılık ve bölgesel floradan kaynaklanabileceği düşünülmektedir. 


\section{Sonuç}

Çalışma sonucunda yetiştirici şartlarında Kıl keçi, Saanen x Kıl keçi (F1, G1 ve G2) melezlerinin 6. ay vücut ölçülerini genotip etkilerken melezlerin bulundukları çevre faktörlerine karşı duyarlılıklarının farklı olduğu tespit edilmiştir.

Çalışmada aynı bakım ve besleme koşullarında Saanen x Kıl G2 melez oğlakların diğer Saanen melezleri ve Kıl keçilerden daha düșük değerlerde vücut ölçülerine sahip olduğu tespit edilmiștir. $\mathrm{Bu}$ sebeple rakımı yüksek olan yerlerde Saanen ırkı seviyesinin \%87.5 olması ile büyüme ve gelişmeyi ifade eden vücut ölçüleri olumsuz yönde etkilenebilir.

Ancak Saanen $x$ Kıl G2 genotipinin bölgeye adaptasyonu ve verimlerinin değerlendirilmesi için daha fazla çalışma yapılmalıdır. Kıl keçilerin vücut özelliklerine bakılarak et verimine yönelik seleksiyon çalışmaları ile et verimi arttırılabilir.

Kıl keçilerin yerli gen kaynağımız olarak korunması ve ıslah edilmesi oldukça önemlidir. Bölgesel olarak Saanen x Kıl keçi melezleme için yapılan araştırma sayısı yeterli değildir. Karadeniz bölgesinde Kıl keçi ve Kıl $x$ Saanen melezleri ile ilgili daha fazla araștırma yapılmalıdır.

\section{Kaynaklar}

Anonim, 2012. Amasya valiliği çevre ve şehircilik il müdürlüğü 2011 çevre durum raporu. (www.csb.gov.tr/db/ced/editordosya/amasya_icdr 2011.pdf), (Erişim tarihi: 08.03.2017).

Bolacalı, M., Küçük, M., 2012. Various body measurements of Saanen kids. Yüzüncü Yıl Üniv. Veteriner Fak. Dergisi, 23: 23-28.

Chacon, E., Macedo, F., Velazquez, F., Paiva, S.R, Pineda, E., McManus, C., 2011. Morphological measurements and body indices for Cuban Creole goats and their crossbreds. Brazilian Journal of Animal Science, 40: 1671-1679.

Çam, M., Olfaz, M., Soydan, E., 2010. Possibilities of using morphometrics characteristics as a tool for body weight prediction in Turkish Hair goats (Kilkeci). Asian Journal of Animal and Veterinary Advances. pp. 1-7.

Cengiz, F., Dellal, G., Karakaya, A., 1995. Akkeçi oğlaklarında büyüme ve gelişme. Tr. J. of Veterinary and Animal Sciences. 19: 429-434.

Düzgüneș, O., Eliçin, A., Akman, N., 2003. Hayvan Islahı. 4. Baskı. Ankara Üniv. Ziraat Fak. Yayınları, Yayın No: 1535, s. 488.
Erduran, H., Yaman, B., 2012. Dağlık şartlarda Kıl x Kıl, Saanen x Kıl ve Alpin x Kıl melezlerine ait büyüme, yaşama gücü özellikleri ve vücut ölçülerinin karşılaștırılması. Uluslararası Türk ve Akraba Topluluklar Zootekni Kongresi, 11-13 Eylül-2012 Isparta. 114.

Kadim, I., Mahgoub, O., Al-Ajmi, D., 2006. Comparative effects of low levels of dietary cobalt and parenteral injections of vitamin B12 on body dimensions in different breeds of Omani goats. Small Ruminant Research, V.66: 244-252.

Keskin, İ., 2012. Malta keçilerinde vücut ölçüleri ile laktasyon süt verimi arasındaki ilişkilerin path analizi ile araştırılması. Iğdır Üni. Fen Bilimleri Enst. Dergisi, 2: 117-120.

Güney, O., Kaymakçı, M., 1997. "Keçilerde Süt Üretimi, 115128". Keçi Yetiştiriciliği (Ed: Kaymakçı M, Așkın Y),. Baran ofset, Ankara.

Mohammed, I., D., Amin, J., D., 1996. Estimating body weight from morphometric measurements of Sahel (Borno White) goats. Small Rum. Res., 24: 1-5.

Pesmen, G., Yardımcı, M., 2008. Estimating the live weight using some body measurements in Saanen goats. Afyon Kocatepe University, Faculty of Veterinary Medicine, Department of Animal Husbandry. Archiva Zootechnica 11: 30-40. (http://www.ibna.ro/arhiva/AZ\%20114/AZ\%201 14\%2003\%20Pesmen\%20\%20Yardimci.pdf), (Erişim tarihi: 28.02.2017).

Riva, J., Rizzi, J., Marelli, S., Cavalchini, G., 2004. Body measurements in Bergamasca sheep. Small Rum. Res., 55: 221-227.

Samuel Fajemilehin O.K., Salako, A.E., 2008. Body Measurement characteristics of the West African Dwarf (WAD) goat in deciduous forest zone of southwestern Nigeria. African Journal of Biotechnology. Vol. 7: 2521-2526.

Şimșek, Ü.G., Bayraktar, M., 2006. Kıl keçi ve Saanen x Kıl keçisi (F1) melezlerine ait büyüme ve yaşama gücü özelliklerinin araştırılması. Fırat Üniv. Sağ. Bil. Dergisi, 20: 229-238.

Șimșek, Ü.G., Bayraktar, M., Gürses, M., 2007. Saanen x Kıl Keçisi F1 ve G1 melezlerinde büyüme ve yaşama gücü özelliklerinin araştırılması. Fırat Üniv. Sağ. Bil. Dergisi, 21: 21-26.

Tüfekci, H., Olfaz, M., 2016. Saanen x Kıl keçi melezi (G1) çebiçlerin erken (7-8 aylık) yaşta damızlıkta kullanılabilme imkanları. Anadolu Tarım Bilimleri Dergisi, 31: 301-307.

Uğur, F., Savaș, T., Dosay, M., Karabayir, A., Atasoglu, C., 2004. Growth and behavioral traits of Turkish 
Saanen kids weaned at 45 and 60 days. Small Rum. Res., 52: 179-184.

Yılmaz, O., Küçük, M., Bolacalı, M., Cak, B., 2013. Investigation of survival rate, growth performance and some body measurements of Saanen x Hair goat $\mathrm{F} 1$ crossbred and pure Hair goat kids raised in semi-Intensive conditions. Bulgarian Journal of Agricultural Science, 19: 835-840. 